\title{
Groundwater discharges to aquatic ecosystems associated with the Table Mountain Group (TMG) aquifer: A conceptual model
}

\author{
W Roets ${ }^{1 *}, Y X^{2}{ }^{2}, L_{\text {Raitt }}{ }^{3}$ and L Brendonck ${ }^{4}$ \\ ${ }^{1}$ SSI Engineers and Environmental Consultants (Pty) Ltd, Postnet suite \#200, P/Bag X6590, George 6530, South Africa \\ ${ }^{2}$ University of the Western Cape, Department of Earth Sciences, P/Bag X17, Bellville 7535, South Africa \\ ${ }^{3}$ University of the Western Cape, Department of Biodiversity and Conservation Biology, P/Bag X17, Bellville 7535, South Africa \\ ${ }^{4}$ Laboratory of Aquatic Ecology, K.U. Leuven, Ch. Deberiotstraat 32, B-3000 Leuven, Belgium
}

\begin{abstract}
This paper reports on a conceptual model that was developed to describe the different groundwater discharge 'types' from the Table Mountain Group (TMG) aquifer, that contributes to the different components of the flow regime in each of the recognised river reaches for streams and rivers associated with the TMG. This model integrates hydrogeological, ecological and geomorphological understandings into an ecohydrological perspective linking ground- and surface water systems. Through geospatial intersections of existing GIS layers a GIS model was also developed to highlight the quaternary catchments containing sensitive aquatic ecosystems that could be vulnerable to groundwater use from the TMG.

The conceptual model demonstrates the intimate link between groundwater from the TMG aquifer and aquatic ecosystems in the mountain and foothill reaches of streams and rivers in the Cape Folded Mountains in particular. It also identifies two primary zones of interaction between groundwater and surface water in the TMG, namely, the 'TMG aquifer daylightdomain', located in the recharge zone, and the 'TMG aquifer surface water interface-domain', located at the discharge end of the aquifer.

The conceptual model clearly indicates the difference between real groundwater, and perceived groundwater contributions to streamflow in the TMG. It is the lower flows of the flow regime that will be most vulnerable to groundwater use from the TMG aquifer in the 'TMG aquifer daylight-domain', which are unfortunately also the most important flows from an ecological perspective. However, any groundwater use from the TMG aquifer will also affect the discharge end of the aquifer, located far from the higher elevation recharge areas, or the point of groundwater abstraction, in lowland settings in the 'TMG aquifer surface water interface-domain'.

The GIS model integrated the conceptual understanding into a management tool by highlight all quaternary catchments associated with TMG containing sensitive aquatic ecosystems and gave the variable vulnerability for each.
\end{abstract}

Keywords: ecohydrology, ecosystem dynamics, groundwater abstraction, river basin management, streamflow regime, TMG aquifer

\section{Introduction}

Rivers are an indispensable part of all ecosystems, rendering many free services to the terrestrial environment, acting as corridors for many ecological processes, and creating linkages for ecological patterns. However, all aquatic ecosystems derive most of their characteristics from the catchments that they drain (Davies et al., 1993). Most of the physical and biological attributes of river ecosystems are also flow dependent, hence the need for rivers to retain the natural flow variability that they evolved with to maintain their ecological integrity (King et al., 2003; Davies et al., 1993). Therefore it is imperative that rivers be managed in an integrated manner recognising the full hydrological system.

A recent focus on large-scale groundwater use from the Table Mountain Group (TMG) Aquifer in the Western Cape Province, and published information on the intimate link between surface water and groundwater (Winter et al. (1999); Midgley and Scott, 1994; Ward and Robinson, 1990), prompted aquatic ecologists

* To whom all correspondence should be addressed.

盄 +27 44802 0600; fax: +27 44802 0650;

e-mail: wietscher@ssi.co.za

Received 10 September 2007; accepted in revised form 27 November 2007. to understand how, and the extent to which groundwater from the TMG contributes to the surface resources, particularly to the different components of the flow regime. Groundwater discharge 'types' had to be conceptualised in the different river reaches (or locations in a landscape), and be linked to the flow regime (hydrology), which is the primary driver of any aquatic ecosystem. This implied the inclusion of geomorphological characteristics of each river reaches in the conceptualisation. Gilvear et al. (2002) support this view by stating that hydrology and geomorphology are intimately related and critical to the ecological quality of rivers. Aspects like river channel, crosssectional geometry, bed material, size and level of bed, and bank stability are all controlled by the flow regime.

The purpose of this paper is to present a conceptual model that was developed to link the different groundwater discharges to the various components of the flow regime, and indicate where in the landscape each would dominate. Simultaneously a GIS model was developed to highlight quaternary catchments sensitive to groundwater use from the TMG. Both models will assist ecohydrologists in understanding the spatial occurrence of the different groundwater discharge 'types' contributing to the flow regime of rivers, and enable the mapping of areas in the Western Cape Province where conflict might exist over disrupted surface discharges resulting from abstracted groundwa- 


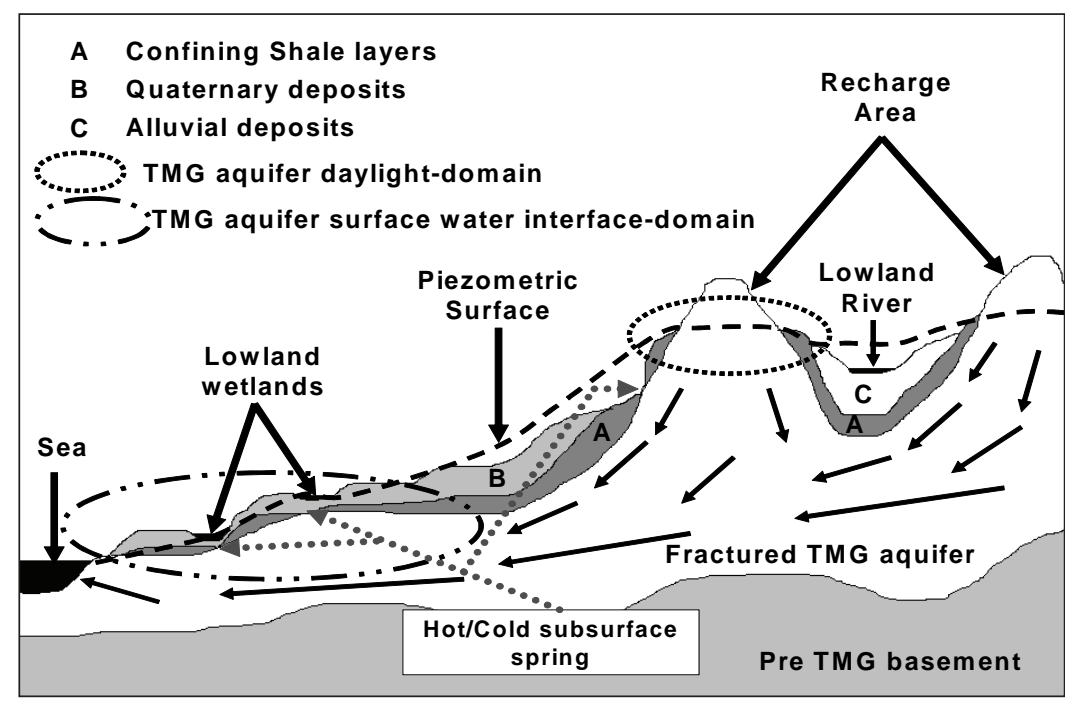

Figure 1

Illustration of how groundwater from the TMG aquifer interacts with surface resources in the 'TMG aquifer daylight-domain' and 'TMG aquifer surface water interface-domain' ter from the TMG aquifer. With the unique characteristics of the rivers of the Cape Floral Kingdom, one of six plant kingdoms of the world (Low and Rebelo, 1996), largely associated with the Cape Fold Belt and the TMG aquifer, it is critical to recognise these important linkages.

The hypothesis for this study was that groundwater discharges from the TMG aquifer contribute to surface resources in two primary areas, firstly as contributions to the flow regime of mountain and foothill streams and rivers in the 'TMG aquifer daylight-domain', and secondly as groundwater contributions to wetlands and other aquatic ecosystems, even marine discharges, all of which are associated with the discharge end of the TMG aquifer far removed from the mountainous recharge areas, in the 'TMG aquifer surface water interface-domain' (see Fig. 1 for the location of both domains).

The objectives of this study were to:

- Conceptualise the different groundwater discharge 'types' contributing to the different components of the flow regime in the different river reaches, particularly in the mountain and foothill streams and rivers in the 'TMG aquifer daylight-domain', located at the recharge areas

- Highlight the difference between perceived groundwater and real groundwater contributions to the flow regime

- Conceptualise the groundwater contribution to the lowland aquatic ecosystems in the 'TMG aquifer surface water interface-domain', located at the discharge end of the aquifer

- Develop a GIS model highlighting areas vulnerable to groundwater use from the TMG in terms of aquatic ecosystems.

\section{Study system}

The conceptualisation approach and GIS model both included the entire extent of the TMG aquifer, and was led by the characteristics of the TMG, the associated ecosystems and geomorphological characteristics within the TMG.

\section{Components of the flow regime in rivers and streams associated with the TMG in the Cape Fold Belt}

Variable flows in rivers, which naturally vary between low flows and high flows, are responsible for creating ecosystem components such as channel type and pattern, water chemistry and temperature, habitat diversity and associated biota, zonation of riparian plants and associated wetlands (Gilvear et al., 2002; King et al., 2000).

King et al. (2003) suggested a flow regime for streams and rivers that is directly applicable to rivers associated with the TMG aquifer. The natural flow regime consists of low- and highflow components. Low flows include the wet- and dry-season baseflows, and high flows include intra-annual floods (Classes I to IV, occurring 6,3 and 2 times per year respectively), and large floods ( 1 in 2, 5, 10, 20 and 50 years respectively).

The characteristics of the different components of the flow regime depend on the relative proportions of each of the groundwater and non-groundwater contribution shaping the hydrograph.

From hydrogeological literature it is clear that precipitation that reaches the earth's surface and infiltrates into the soil moves under gravity and percolates downwards to recharge the groundwater zone, or else it flows laterally close to the surface as interflow.

\section{Hydrogeological perspective on the mechanisms of groundwater and surface water interactions in the TMG}

Increased demands for freshwater worldwide have led to the realisation that development of either of these resources affects the quantity and quality of the other (Winter et al., 1999; Ward and Robinson, 1990). Midgley and Scott (1994) demonstrated that even floods in rivers can comprise largely discharged groundwater depending on the geological setting.

The basic interaction between groundwater and surface water can be summarised in two ways, i.e. recharge of groundwater by surface water, and discharge of groundwater to surface water. However, this groundwater movement to and from streams is very dynamic and can change with variations in the level of a stream or its adjacent water table. In a matter of hours, influent seepage in a stream (gaining stream) may supersede effluent seepage (losing stream) and vice versa (Winter et al., 1999). Figure 1 shows how deep circulating groundwater can discharge to surface resources in both the 'TMG aquifer daylightdomain' and 'TMG aquifer surface water interface-domain'. In the 'TMG aquifer daylight-domain' groundwater from the TMG is discharged at geological contacts between the confining shale layers and the TMG as spring discharges, and/or at fractures near the surface and contributes to surface flow in mountain and foothill streams. In the 'TMG aquifer surface water interface- 
domain' groundwater is either discharged directly (as marine discharges), or as deep subsurface hot or cold springs that may recharge primary aquifers associated with lowland wetlands. The temperature of these springs will depend on the depth at which water circulated.

\section{Influence of geomorphology on types of rivers associated with the TMG}

Geomorphology plays an important role in the rivers' make-up or characteristics, and it needs to be considered to fully understand the link between groundwater and surface water. Pool, riffle, rapid sequences, single or braided river beds, flat fluvial beds, flood plains, bed structure, etc. are all determined by the geomorphology and the flow regime (Gilvear et al., 2002; King et al., 2000). These characteristics will also largely determine the type and quantity of groundwater that is discharging to the surface resource.

Moon and Dardis (1988) indicated how the underlying geological structure determines the drainage patterns of rivers. Both dendritic (Fig. 2A) and parallel (Fig. 2B) drainage patterns develop on uniform lithologies and where there are no controlling joints or fractures. Where faults, joints, or other lineaments control drainage it will develop rectangular (Fig. 2C), while alternating resistant or less resistant strata will promote the development of trellised drainage. In settings where up-doming has occurred annular drainage patterns will be present, and in landscapes where tectonic activity is present, radial and centripetal drainage configurations will manifest. In any catchment one or several of these patterns may be present since these patterns are entirely dependent on the underlying structure (Moon and Dardis, 1988).

These drainage manifestations will affect the type of groundwater discharges characterising certain sections of a river system, particularly streams and rivers, and other aquatic ecosystems, associated with the TMG. Table 1 (next page) summarises the occurrence of these drainage patterns in the TMG.

\section{Recognised groundwater discharge types to surface resources applicable to rivers associated with the TMG}

Hydrogeologists recognise that runoff in rivers associated with the TMG is generated by channel precipitation, overland flow
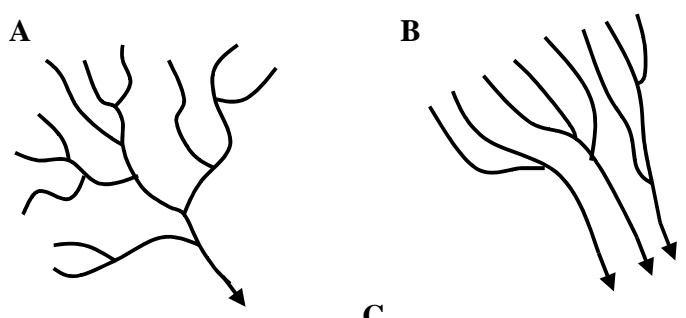

C

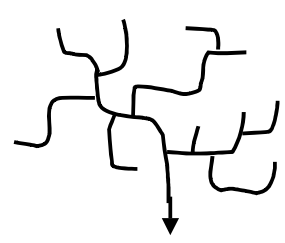

Figure 2

Drainage patterns in different structural settings: $(A)$ dendritic,

(B) parallel, (C) rectangular (surface runoff or quick-flow), interflow (which may include translatory flow, also called piston flow) and groundwater flow (Xu and Beekman, 2003; Xu et al., 2002; Winter et al., 1999). According to these authors it is commonly accepted that a river hydrograph (graph showing variable flows in a river over time) consists of baseflows (low flows) and stormflows (high flows). Baseflows consist of mainly groundwater discharges and or interflow, while stormflows include direct runoff (Xu et al., 2002), translatory flow, interflow and in-channel precipitation (Xu and Beekman, 2003; Winter et al., 1999). Another important groundwater contribution to the hydrograph is bank storage (infiltrated water into river banks or flood plains after flooding has occurred), which does not really fit into any of the above categories, or alternatively could be part of more than one of the above types.

For the purpose of the conceptual model there was a definite need to distinguish between real groundwater discharges, and perceived groundwater discharges. Perceived groundwater discharges include interflow and translatory flow, because this water never became part of the groundwater table. By separating real and perceived groundwater discharges, and conceptualising the relative proportions of each type contributing to each component of the flow regime distinguished for each river reach, it would enable the determination of the ecological significance of real groundwater from the TMG.

The characteristics of the four components of runoff, and the relative proportions of each component present, determine the shape of the hydrograph in any river associated with the TMG. Due to the complex flow composition resulting from local variations in rainfall, infiltration and antecedent conditions, it may be difficult to isolate each component of runoff in a hydrograph.

\section{Mechanisms of groundwater surface water interactions} in mountainous areas associated with the TMG

$\mathrm{Xu}$ and Beekman (2003) suggested that interflow accounts for part of the baseflow in mountainous catchments where rivers are associated with the TMG. The interflow results from the shallower weathered zone of the alluvial and slope deposits in the mountains. These deposits may serve as a reservoir for storing water during the rainy season while at the same time allowing for percolation to the deeper groundwater reservoir, often through a network of fractures. This reservoir would discharge to the streams' baseflow and cause continuity of flow. Translatory flow occurs under similar conditions as interflow, but is discharged during or after a follow-up recharge event that pushes the 'interflow' out into the stream stage. Groundwater discharges become more dominant in the foothill reaches, which is the primary groundwater discharge zone. Beyond the foothill reaches groundwater surface water interactions with the TMG aquifer would be expected to be less important due to the confining shale layers that isolate the aquifer.

The semi-confined to confined nature of the TMG aquifer stems from its deep diving synclinal nature which is sealed off on the sides by the shale layers of the Cederberg Group (Kotze, 2002). Hence the postulation that the interface between the groundwater and surface resources is largely located in the geological contact areas of the mountain and foothill zones of the Cape Folded Mountain ranges. It is at these geological contacts, and or fractures or faults, that cold or hot springs emanate in the landscape. At the discharge end of the aquifer similar discharges will occur in aquatic ecosystems far away from the recharge areas in lowland settings, or marine environments. 


\begin{tabular}{|c|c|c|c|}
\hline \multicolumn{4}{|c|}{ 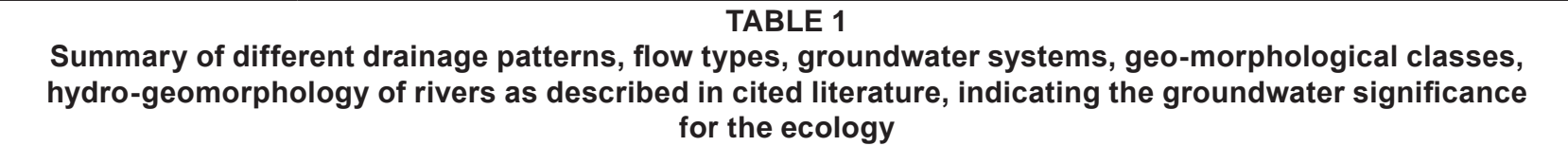 } \\
\hline Parameter type & $\begin{array}{l}\text { Headwater and mountain } \\
\text { reaches }\end{array}$ & Foothill reaches & Lowland reaches \\
\hline $\begin{array}{l}\text { Drainage patterns } \\
\text { (Moon and Dardis, } \\
\text { 1988) }\end{array}$ & Dendritic, parallel & Dendritic, rectangular & Dendritic \\
\hline $\begin{array}{l}\text { Dominant flow type(s) } \\
\text { (Xu and Beekman, } \\
\text { 2003; Xu et al., 2002) }\end{array}$ & $\begin{array}{l}\text { Interflow (IF) dominated on } \\
\text { local scale. Surface runoff } \\
\text { and preferential flow. Some } \\
\text { translatory flow. Baseflow in } \\
\text { TMG (Perennial). No bank } \\
\text { storage. }\end{array}$ & $\begin{array}{l}\text { Baseflow dominated but with } \\
\text { interflow, some bank storage, } \\
\text { surface runoff and channel } \\
\text { precipitation. }\end{array}$ & $\begin{array}{l}\text { Characterised by bank storage, Base } \\
\text { flow increase with bank storage, Sur- } \\
\text { face runoff, regional and local ground- } \\
\text { water discharges possible - mainly } \\
\text { alluvial storage. }\end{array}$ \\
\hline $\begin{array}{l}\text { Groundwater system } \\
\text { (regional or local) } \\
\text { (Xu and Beekman, } \\
\text { 2003; Xu et al., 2002; } \\
\text { Winter et al., 1999) }\end{array}$ & $\begin{array}{l}\text { Local scale - interflow. } \\
\text { Regionally - recharge area } \\
\text { and may have local and } \\
\text { regional groundwater dis- } \\
\text { charge in the TMG. }\end{array}$ & \begin{tabular}{|l|} 
Regionally a runoff area. \\
Groundwater discharge is \\
local but regionally significant. \\
Discharge and recharge area \\
(through hyporheos at pool-rif- \\
fle sequences). \\
\end{tabular} & $\begin{array}{l}\text { Regionally recharging alluvial aqui- } \\
\text { fers. Local bank storage. May get } \\
\text { groundwater discharge from regional } \\
\text { and local groundwater systems. }\end{array}$ \\
\hline $\begin{array}{l}\text { Geomorphological } \\
\text { classification (Gilvear } \\
\text { et al., 2002; King et al., } \\
\text { 2000) }\end{array}$ & $\begin{array}{l}\text { Braided, to single channel, } \\
\text { deeply incised, fracture and } \\
\text { lineaments controlled. High } \\
\text { gradient, bedrock cobble bed. }\end{array}$ & $\begin{array}{l}\text { Stream controlled by mainly } \\
\text { bed morphology (pool riffle } \\
\text { sequences). }\end{array}$ & $\begin{array}{l}\text { Meandering, topographically flat areas, } \\
\text { fluvial erosion develop terrain horizon- } \\
\text { tally, alluvial deposits. }\end{array}$ \\
\hline $\begin{array}{l}\text { Hydro-geomorpho- } \\
\text { logical typing (Xu and } \\
\text { Beekman, 2003; Xu et } \\
\text { al., 2002; Winter et al., } \\
\text { 1999) }\end{array}$ & $\begin{array}{l}\text { Constantly losing or gaining } \\
\text { streams. } \\
\text { Regional groundwater level is } \\
\text { constantly below the stream } \\
\text { stage. Fed by confined aquifer } \\
\text { and or local interflow. }\end{array}$ & \begin{tabular}{|l|} 
Intermittent streams. Gaining \\
and losing stream alternate at \\
pool riffle sequences. Ground- \\
water discharges towards \\
streams during dry period and \\
vice versa during wetter cycle. \\
River recharges aquifers during \\
floods (bank storage).
\end{tabular} & $\begin{array}{l}\text { Gaining streams with or without bank } \\
\text { storage. Groundwater levels consist- } \\
\text { ently higher that the river stage. Base- } \\
\text { flow component increase in an S-curve } \\
\text { or straight line as a function of the } \\
\text { presence or absence of bank storage. } \\
\text { Groundwater from TMG unlikely to } \\
\text { play role directly. }\end{array}$ \\
\hline $\begin{array}{l}\text { Significance of } \\
\text { groundwater contri- } \\
\text { butions from TMG for } \\
\text { ecology (Flow regime) }\end{array}$ & $\begin{array}{l}\text { Significant where baseflow } \\
\text { from TMG is significant. } \\
\text { Interflow may be affected } \\
\text { by use from TMG because } \\
\text { interflow is also a function } \\
\text { of rejected recharge of TMG } \\
\text { aquifer. }\end{array}$ & $\begin{array}{l}\text { Highly significant. This is } \\
\text { where groundwater discharge } \\
\text { from the TMG is most likely } \\
\text { and contributing significantly } \\
\text { to the flow regime. Flows will } \\
\text { be affected by piezometric } \\
\text { head drop or development of } \\
\text { the draw down cone (cone of } \\
\text { depression). }\end{array}$ & $\begin{array}{l}\text { Unlikely to significantly impact direct } \\
\text { discharges from TMG aquifer. May } \\
\text { affect discreet TMG regional flow } \\
\text { discharges in specific settings because } \\
\text { aquifer discharge will be impacted by } \\
\text { use as given by: } \\
\text { ADJUSTED RECHARGE } \\
\text { - REDUCED OUTFLOW } \\
\text { - PUMPING } \\
\text { + STORAGE LOSS = 0 } \\
\text { (Acknowledges that recharge increase } \\
\text { and outflow decrease in response to } \\
\text { lowered water table) (Xu and Beek- } \\
\text { man, 2003). }\end{array}$ \\
\hline
\end{tabular}

\section{GIS based model}

In order to give effect to the conceptual understanding of the groundwater discharges in the 'TMG aquifer daylight-domain', and 'TMG aquifer surface water interface-domain', it was essential to develop a tool by which this understanding on the intimate link between groundwater and surface water, could be put into practice.

Haywood et al. (2002), state that GIS has become an accepted tool for the management and analysis of spatial data in the $20^{\text {th }}$ century. Semeniuk and Semeniuk (1994) and Commander (2000) also identified the use of GIS as the most effective means of combining, synthesising, comparing and correlating various databases in an attempt to identify groundwater-dependent ecosystems.
Current advances in GIS technology were used to develop different GIS layers in order to map areas where TMG aquifer discharges can be expected, and where these discharges can be expected to have an ecological effect in the landscape, particularly with regard to aquatic ecosystems.

\section{Materials and methods}

\section{Methodology}

\section{Conceptual model}

After a thorough literature survey through hydrogeological, geomorphological and ecological literature applicable to the TMG, a new integrated conceptual understanding was developed on 
how groundwater interacts with aquatic ecosystems associated with the TMG. This conceptual understanding culminated in the formulation of a conceptual model linking the 'acknowledged groundwater discharge mechanisms' realised in hydrogeological literature, to the 'acknowledged components of the flow regime' in ecological literature, and to 'geomorphologically recognised river reach' (position in the landscape).

This integration of the three different disciplines during the conceptualisation process resulted in the three basic steps that followed. These steps culminated in the new ecohydrological understanding of groundwater surface water interactions.

The $\mathbf{1}^{\text {st }}$ step was the compilation of a flow diagram to indicate how catchment precipitation results in the different groundwater discharges 'types' (groundwater proper and perceived groundwater) and how these contribute to runoff.

The $2^{\text {nd }}$ step was the integration of the different components of hydrogeology, ecology and geomorphology by tabulating the information on the different drainage patterns, flow types, groundwater systems, geomorphological classes and the hydrogeomorphology of rivers associated with the TMG, and indicating the groundwater significance for the ecology.

The $3^{\text {rd }}$ step was the design of a conceptual model to link the different groundwater discharge 'types' to the flow regime and to a particular position in the landscape (river reach). This was achieved by listing the components of the flow regime in the lefthand columns of a matrix, with the different river reaches in the top rows of the tabulated matrix. The rest of the matrix was then populated with all the different groundwater discharge 'types' expected for each component of the flow regime, and in each river reach. The conceptual model also distinguished between the two primary areas where interaction between aquatic ecosystems and groundwater from the TMG aquifer could be expected.

\section{GIS model}

Arcview 3.3 GIS software was used to develop this model, and all the data were in WGS84 format. The computer (hardware) that was used consisted of a Pentium 4 Prescot processor, with 512 MG RAM, 80G hard drive and on line graphics. An accompanying USB dongle was used to activate Arcview 3.3. Existing GIS layers were used, and through geospatial intersections new data layers were developed. Each data layer was selected after careful consideration of the criteria to develop the necessary outcome.

Existing GIS data layers were used during several geospatial intersections. These geospatial intersections were executed by following two basic steps.

The $\mathbf{1}^{\text {st }}$ step (Fig. 3) shows how the TMG Aquifer shape file (developed by Fortuin, 2004) was geospatially intersected with an existing DWAF layer containing quaternary catchments. Geospatial intersections are an established tool to integrate different spatially defined layers giving a new spatial outcome. The resultant layer was geospatially intersected with an existing Cape Action Plan for People and the Environment (C.A.P.E.) (Cowling et al., 1999) layer, which highlighted aquatic ecosystem importance for fish conservation. The C.A.P.E. layer was based on identified catchments containing hotspots for threatened and endemic fish richness, where recruiting and strong populations of several indigenous fish were present (Impson et al., 1999). This was followed by geospatially intersecting the resultant layer with the 'Groundwater Development Potential' layer of Fortuin (2004), which culminated in a GIS layer showing all quaternary catchments having both a high groundwater development potential and varying degrees of 'Sensitive Aquatic
Ecosystems' associated with the TMG. The 'Sensitive Aquatic Ecosystems' layers were thus based on the criteria used to show quaternary catchments' sensitivity from a fish conservation perspective (fish as indicator of ecosystem vulnerability) and on the criteria for developing 'Groundwater Development Potential'.

The 'Groundwater Development Potential' layer of Fortuin (2004) resulted from a geospatial intersection of amongst others, a groundwater 'Exploitation-'and 'Exploration Potential' Map for the TMG Aquifer Systems covering the entire TMG area. The Exploitation Potential Map considered the resource and recharge to show the potential of an area to sustain largescale abstraction. Rainfall was used to estimate the mean annual effective recharge using raster-based grid analysis. The methodology used by Fortuin (2004) was based on the Maxey-Eakin empirical method but had been adjusted to consider other critical factors such as lithology and slope. The results showed that high recharge coincided with TMG outcrop areas in mountainous regions, but that the accessibility to these regions could be problematic where the slope was in excess of $15 \%$. Fortuin (2004) then checked and verified the resulting recharge using the 'Harvest Potential' map developed by DWAF. Fortuin also considered borehole siting because it may not always be possible to find suitable drilling targets to site production boreholes capable of delivering the required yields. The Exploration Potential Map developed by Fortuin (2004) assessed the accessibility and drilling success of a borehole according to a reclassification of Vegter's Borehole Prospects map.

Fortuin (2004) then geospatially intersected the 'Exploitation-' and 'Exploration' Potential Maps and produced a Groundwater Development Potential Map, showing a qualitative rating for the development of large-scale abstraction schemes.

However, the 'Sensitive Aquatic Ecosystems' layers did not include any buffer areas around the latter layers. As a $2^{\text {nd }}$ step (Fig. 4) a buffer area around the TMG aquifer shapefile was included. This was achieved by using a buffer function in Arcview 3.3, which inserted a buffer area around the entire TMG aquifer shape file. This polygon was defined to extend $10 \mathrm{~km}$ away from the outside perimeter of the TMG aquifer. Xu et al. (2002) proposed a realistic range of influence when abstracting water from the TMG aquifer to be between $3 \mathrm{~km}$ and $10 \mathrm{~km}$ from the point of abstraction. The $10 \mathrm{~km}$ buffer shape file was geospatially intersected with the quaternary catchment shape file. The

\section{GIS Model: Step 1, developing a layer to show Sensitive Aquatic Ecosystems associated with the TMG}
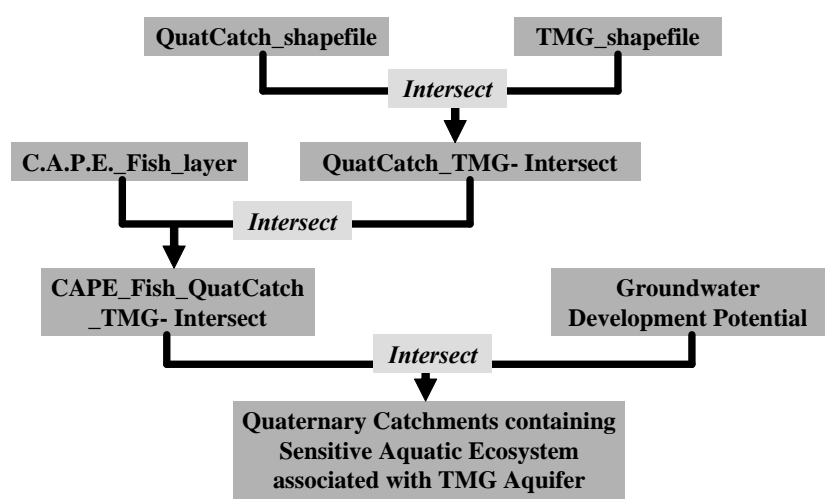

Figure 3

Diagram showing the development of the GIS model to show the sensitive aquatic ecosystems associated with the TMG 


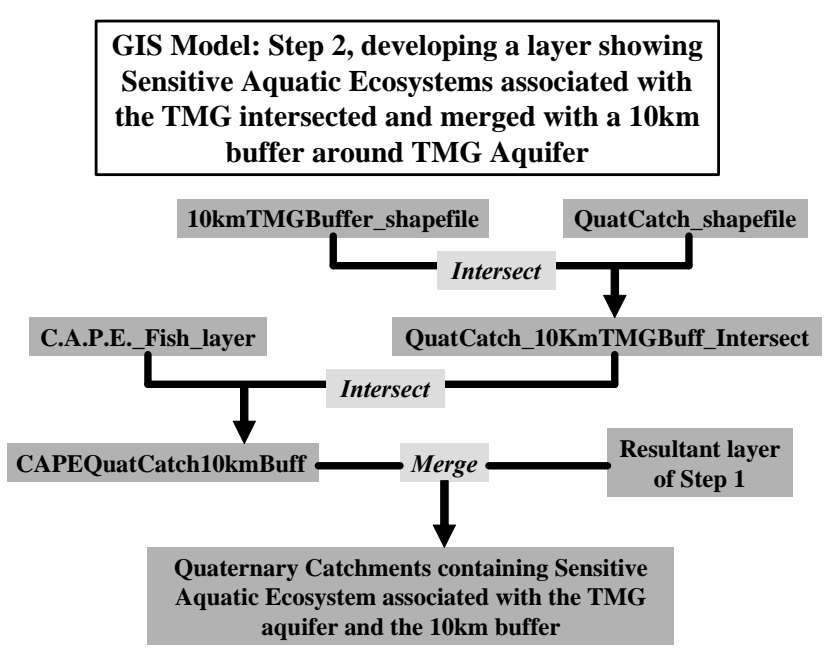

Figure 4

Diagram showing the development of the second step in the GIS model to show the sensitive aquatic ecosystems associated with the TMG after inclusion of quaternary catchments in the $10 \mathrm{~km}$ buffer around the TMG aquifer

resultant intersection was then geospatially intersected with the CAPE fish conservation layer that resulted in a layer showing the quaternary catchments containing sensitive aquatic ecosystems in the $10 \mathrm{~km}$ buffer area around the TMG aquifer.

The latter layer was then geospatially merged with the 'Sensitive Aquatic Ecosystem' layer to give the final spatial view of all the quaternary catchments that contain sensitive aquatic ecosystems associated with the TMG aquifer, including those in the vitally important buffer area.

\section{Results}

\section{Conceptual model}

Figure 5 gives the results of the $1^{\text {st }}$ step on how precipitation (rainfall, snow and mist), within a particular basin or catchment, becomes part of channel flow through overland flow; in-channel precipitation; and after infiltration into the soil.

Infiltrated water (perceived groundwater) takes one or more of three different routes before it becomes channel flow. The first type of discharge is interflow that never becomes part of the water table (non-groundwater). Rapid interflow discharges would result from the presence of preferential flow paths or where the soil horizon acts as a flow barrier, which hinders direct downward percolation of water. It would also result from rejected recharge when the aquifer is fully recharged. Delayed interflow may result from partially saturated flow via a perched water table, or where geometric configurations of fractured networks led to formulation of interflow. The onset of both will be dependent on the antecedent soil moisture conditions.

Translatory flow will be discharged to streams and rivers in a similar geomorphological setting like interflow (also nongroundwater). The only difference is that translatory flow results from a previous recharge event that infiltrated into the soil, never became part of the water table, and is flushed or pushed out by a next recharge event through infiltration before it could discharge under gravitational forces. The difference between delayed and rapid translatory flow is similar to that of interflow and would happen under similar antecedent conditions.

The $3^{\text {rd }}$ type of discharge resulting from infiltration is real groundwater discharges. This water recharges the water table (piezometric surface) before it gets discharged to the river or stream. These discharges may happen in different ways. The most common would be spring discharges, and/or seeps, both of which are normally associated with geological contact areas or geological faults zones (Kotze, 2002). The geological groups that make contact will have different water permeabilities where the one acts as an aquatard. These aquifer boundary conditions will give rise to a semi-confined to confined aquifer that will discharge water at these geological contacts, or faults, provided that the piezometric surface (water table) is high enough or fully recharged. In this type of setting rejected recharge will be discharged as interflow. Groundwater discharges may also discharge in a diffuse manner through the hyporheos of a stream or river where these geological contact scenarios exists, or at underlying faults or fractures.

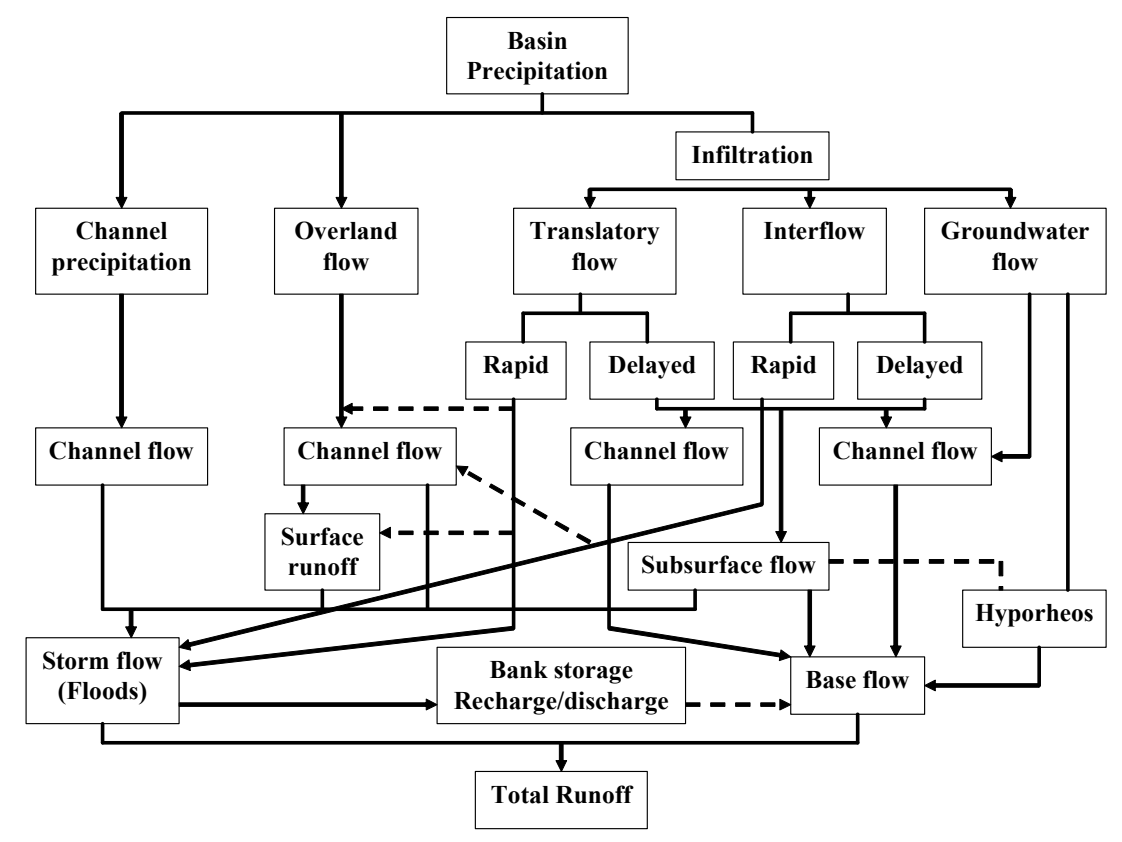

Figure 5

Schematic representation of the proposed groundwater contributions to the flow regime in rivers associated with the Table Mountain Group aquifer (dotted lines represent possible discharge connections) 
From Fig. 5 it is clear that translatory flow, interflow, and groundwater discharges are mainly responsible for baseflows in rivers and streams. The relative proportion of each type present will depend on the stratigraphy of the area, the slope, geomorphology and antecedent conditions.

Channel precipitation and overland flow discharges will mainly occur under heavy precipitation events and contribute mainly to stormflows as small, medium and large floods. However, overland flow may also result from aspects such as steep slopes, bad land use, etc. Channel precipitation and overland flow constitute surface runoff, which could also include subsurface and translatory discharges. Under stormflow conditions the river banks will overflow and be recharged to form the very important bank storage reservoir. Bank storage essentially reacts as an unconfined or primary aquifer, which would slowly release its water to the stream for as long as the streambed is lower than the water table. All of the above discharges ultimately equate to the total runoff for the catchment.

The $2^{\text {nd }}$ step under methodology culminated in Table 1 , which summarises the cited literature on the different drainage patterns, flow types, groundwater systems, geo-morphological classes and the hydro-geomorphology of rivers associated with the TMG, also indicating the groundwater significance for the ecology.

From Table 1 it is clear that the dominant drainage patterns associated with the TMG domain are dendritic, parallel and rectangular, particularly in the TMG-dominated mountain ranges. The dominant groundwater flow types for the four river reaches are: interflow dominating in the headwater and mountain river reaches, with some translatory flow and groundwater discharges (as baseflow) from the TMG. Bank storage is unlikely to occur in these reaches. In the foothill reaches, the major groundwater discharge zone, groundwater discharges dominate baseflow with some interflow. Stormflows and floods result from interflow, translatory flow, bank-storage discharges, channel precipitation and surface runoff. The lowland rivers are getting most of their flow from the upper reaches with some surface runoff, channel precipitation and bank-storage discharges. This is the regional recharge and or discharge zone for the lowland primary aquifers (alluvial storage).

Geomorphologically the headwater and mountain river reaches vary from deeply incised, fracture and lineament controlled, to braided river flows consisting mainly of bed rock and cobble beds giving rise to dendritic and parallel drainage. In the foothill areas streams are controlled by bed morphology and alluvial fans resulting in dendritic and rectangular drainage. The lowland rivers meander as they hit the flatter fluvial areas where the terrain developed horizontally into a dendritic drainage pattern.

Hydro-geomorphological characteristics for the four river reaches vary between constantly losing or gaining streams in the headwater and mountain reaches, to intermittent streams, alternating between gaining and losing sequences in the foothill reaches, and gaining streams with or without bank storage in the lowland reaches. In the headwater and mountain reaches the water table will be mostly below the stream stage, but in the foothill reaches it can be alternating from being above and below, and in the lowland reaches the water table will be mostly above the stream stage. However, in the lowland river it is a different aquifer's water table (primary aquifer) that will be mostly above the stream stage, whereas in the mountain and foothill reaches it is the TMG aquifer water table that applies.

The ecological significance of the groundwater contributions from the TMG is most significant in the foothill reaches, which are the primary groundwater discharge area for streams and rivers associated with the TMG. It can also be significant in the mountain reaches where the river or stream is connected to the TMG aquifer, or where there are significant real groundwater discharges contributing to flow. In the lowland river reaches the TMG discharges are unlikely to have a significant direct role to play in its flow regime other than it's indirectly contribution to flows in these reaches. If flow of the upper reaches is significantly affected by groundwater use it will ultimately affect the lowland reaches by reducing the flows and subsequently the recharge of the primary aquifers associated with these rivers.

Discharges from the TMG in the lowland reaches will be restricted to faults or fractures where deep flow discharges may be possible as hot or cold springs that may recharge primary aquifers from below. In the latter case these discharges may support wetlands, estuaries or even marine discharges. These discharges will occur at or near the discharge end ('TMG aquifer surface water interface-domain') of the aquifer and will be ecologically significant.

Table 2 represents the conceptual model that culminated from the $3^{\text {rd }}$ step mentioned under methodology. The conceptual model consists of a matrix where the top rows (left to right) of Table 2 lists the different river reaches, while the second left hand column list the different components of the flow regime (top to bottom), with the far left hand column showing the two primary domains within which the listed discharges occur. The rest of matrix between the upper and left axis of Table 2 were populated with the conceptualised 'groundwater discharge types' (real groundwater and perceived groundwater) contributing to each component of the flow regime in each of the different river reaches. Geo-morphological-, hydro-geomorphological-, and flow regime (hydrology and hydraulics) information were used in the compilation of the matrix (Table 2). The relative proportions of the four components of runoff (interflow, translatory flow, groundwater discharge and surface contributions), were conceptualised for each component of the flow regime (baseflow or stormflow scenarios) in each of the river reaches to determine the importance (ecological significance) of real groundwater from the TMG to each.

The colours from red to light yellow indicate the relative importance of real groundwater discharges from the TMG aquifer to each 'river reach type' and each flow regime component. Red represents a very high importance of real groundwater discharges to maintain that component of the flow regime for that particular river reach. The lighter the colour gets the less important real groundwater discharges become. Similarly, the more important the groundwater discharge is for each component of the flow regime in each river reach, the more important it is for the ecological functioning of the aquatic ecosystem. These same colours subsequently indicate the vulnerability of each component of the flow regime in each river reach to groundwater use from the TMG aquifer, and therefore the vulnerability of the ecological integrity of the aquatic ecosystem to the use of groundwater from the TMG.

\section{GIS model}

The data layer shown in Fig. 6 culminated from the geospatial intersection process as given in Fig. 3 ( $\mathbf{1}^{\text {st }}$ step). This layer clearly shows all the quaternary catchments containing sensitive aquatic ecosystems in the TMG aquifer that is vulnerable to groundwater use in varying degrees. The 'Critical' sensitive quaternaries are the most vulnerable to groundwater use, followed by the others from 'Very High' to 'Low'. Table 3 gives the 
TABLE 2

Proposed 'Conceptual model' showing groundwater discharge types contributing to streamflow for each river reach associated with the TMG (A and B represents the discharges in 'TMG aquifer daylight-domain' and 'TMG aquifer surface water interface-domain' respectively)

\begin{tabular}{|c|c|c|c|c|c|c|c|}
\hline & \begin{tabular}{|l|} 
Flow \\
regime
\end{tabular} & $\begin{array}{l}\text { Flow } \\
\text { regime }\end{array}$ & $\begin{array}{l}\text { Headwater reach } \\
{ }^{*} \text { water table belo }\end{array}$ & w stream & $\begin{array}{l}\text { Mountain reach } \\
* \text { water table }\end{array}$ & $\begin{array}{l}\text { Foothill reach } \\
\text { * water table interchange- }\end{array}$ & $\begin{array}{l}\text { Lowland reach } \\
{ }^{*} \text { water table above stream }\end{array}$ \\
\hline & & & Ephemeral & Perennial & \begin{tabular}{|l|} 
(mostly perennial \\
in TMG)
\end{tabular} & (mostly perennial in TMG) & (mostly perennial in TMG) \\
\hline A & $\begin{array}{l}\text { Low } \\
\text { flow }\end{array}$ & $\begin{array}{l}\text { Dry } \\
\text { season } \\
\text { baseflow }\end{array}$ & $\begin{array}{l}\text { - Perched } \\
\text { spring dis- } \\
\text { charge } \\
\text { - Interflow } \\
\text { * (Interflow } \\
\text { dominated } \\
\text { reach) }\end{array}$ & $\begin{array}{l}\text { - Groundwater } \\
\text { (Perched } \\
\text { springs) } \\
\text { - Interflow } \\
\text { * (Interflow } \\
\text { dominated) }\end{array}$ & $\begin{array}{l}\text { - Groundwater } \\
\text { (TMG springs } \\
\text { + seeps) } \\
\text { - Interflow } \\
\text { dominated in } \\
\text { most settings } \\
\text { (Interflow might } \\
\text { increase as a } \\
\text { function of } \\
\text { rejected recharge } \\
\text { to TMG aquifer } \\
\text { in some settings) } \\
\end{array}$ & $\begin{array}{l}\text { Groundwater from moun- } \\
\text { tain reach (TMG springs) } \\
\text { and other discharges } \\
\text { (hyporheic) } \\
\text { Primary groundwater } \\
\text { discharge zone from TMG } \\
\text { (Confined to semi-confined } \\
\text { aquifer) } \\
\text { Interflow } \\
\text { Limited bank-storage dis- } \\
\text { charge possible depending } \\
\text { on antecedent conditions }\end{array}$ & $\begin{array}{l}\text { Groundwater from foothill } \\
\text { reach and discreet TMG } \\
\text { discharges (hyporheic etc.) } \\
\text { Bank storage discharge } \\
\text { depending on antecedent } \\
\text { conditions } \\
\text { Water table (alluvial uncon- } \\
\text { fined aquifer not confined to } \\
\text { semi-confined TMG aquifer) }\end{array}$ \\
\hline & & $\begin{array}{l}\text { Wet } \\
\text { season } \\
\text { baseflow }\end{array}$ & $\begin{array}{l}\text { - Perched } \\
\text { spring dis- } \\
\text { charge } \\
\text { - Increased } \\
\text { interflow }\end{array}$ & $\begin{array}{l}\text { - Increased } \\
\text { spring flow } \\
\text { - Increased } \\
\text { Interflow } \\
\text { * (Interflow } \\
\text { dominated) }\end{array}$ & $\begin{array}{l}\text { - Increased base- } \\
\text { flow (result of } \\
\text { increased TMG } \\
\text { groundwater } \\
\text { discharge) } \\
\text { - Increased Inter- } \\
\text { flow (Interflow } \\
\text { might increase } \\
\text { as a function of } \\
\text { rejected recharge } \\
\text { to TMG in some } \\
\text { settings) } \\
\text { - Possibility exists } \\
\text { for some delayed } \\
\text { translatory flow } \\
\text { in some settings }\end{array}$ & $\begin{array}{l}\text { In creased baseflow (from } \\
\text { mountain reach) } \\
\text { Primary groundwater } \\
\text { discharge throughout reach } \\
\text { (hyporheic) } \\
\text { Increased Interflow } \\
\text { Delayed translatory flow } \\
\text { Limited bank-storage } \\
\text { discharge (depending on } \\
\text { antecedent conditions) }\end{array}$ & $\begin{array}{l}\text { - In creased baseflow (from } \\
\text { foothill reach) } \\
\text { - Water table rise } \\
\text { - Limited interflow possible } \\
\text { - Limited delayed translatory } \\
\text { flow possible } \\
\text { - Bank-storage discharge } \\
\text { (depending on antecedent } \\
\text { conditions) }\end{array}$ \\
\hline & $\begin{array}{l}\text { High } \\
\text { Flow }\end{array}$ & $\begin{array}{l}\text { Intra- } \\
\text { annual } \\
\text { floods } \\
\text { (smaller } \\
\text { floods) }\end{array}$ & $\begin{array}{l}\text { - Baseflow } \\
\text { - Increased } \\
\text { interflow } \\
\text { - Surface runoff }\end{array}$ & $\begin{array}{l}\text { Baseflow } \\
\text { (recharge } \\
\text { dependent) } \\
\text { Increased } \\
\text { Interflow } \\
\text { - Surface runoff }\end{array}$ & \begin{tabular}{|l|} 
- Baseflow com- \\
ponent \\
- High degree \\
of interflow \\
(rejected \\
recharge to TMG \\
aquifer) \\
- Some degree of \\
translatory flow \\
in some settings \\
- Surface runoff
\end{tabular} & $\begin{array}{l}\text { - Increased baseflow } \\
\text { - Increased groundwater } \\
\text { discharge throughout reach } \\
\text { (hyporheic, etc.) } \\
\text { - Increased interflow } \\
\text { - Translatory flow } \\
\text { - Surface runoff } \\
\text { - Increased flow from moun- } \\
\text { tain reach } \\
\text { - Tributary discharges } \\
\text { - Limited bank-storage } \\
\text { recharge depending on } \\
\text { antecedent conditions } \\
\end{array}$ & $\begin{array}{l}\text { - Increased baseflow } \\
\text { - Water table rise } \\
\text { - Limited interflow possible } \\
\text { - Limited translatory flow } \\
\text { possible } \\
\text { - Surface runoff } \\
\text { - Increased flow from foothill } \\
\text { reach } \\
\text { - Tributary discharges } \\
\text { - Bank-storage discharge or } \\
\text { recharge depending on ante- } \\
\text { cedent conditions }\end{array}$ \\
\hline & & $\begin{array}{l}\text { Large } \\
\text { floods }\end{array}$ & $\begin{array}{l}\text { - Baseflow } \\
\text { - High degree of } \\
\text { interflow } \\
\text { - Higher surface } \\
\text { runoff }\end{array}$ & $\begin{array}{l}\text { - Baseflow } \\
\text { (recharge } \\
\text { dependent) } \\
\text { - High degree of } \\
\text { interflow } \\
\text { - Higher surface } \\
\text { runoff }\end{array}$ & \begin{tabular}{|l|} 
- Elevated base- \\
flow \\
- Very high \\
degree of Inter- \\
flow (preferential \\
flow paths) \\
- High degree of \\
translatory flow \\
possible in some \\
settings \\
- Higher surface \\
runoff
\end{tabular} & \begin{tabular}{|l} 
- Elevated baseflow \\
- Increased groundwater \\
discharge throughout reach \\
(hyporheic) \\
- Increased Interflow (pref- \\
erential flow paths) \\
- High degree of translatory \\
flow \\
- High tributary discharges \\
- Bank-storage recharge \\
- High surface runoff
\end{tabular} & $\begin{array}{l}\text { - Elevated baseflow } \\
\text { - High water table rise } \\
\text { - Limited interflow (preferen- } \\
\text { tial flow paths) } \\
\text { - Limited translatory flow } \\
\text { possible } \\
\text { - Higher surface runoff } \\
\text { - High tributary discharges } \\
\text { - Bank-storage recharge } \\
\text { - Channel precipitation }\end{array}$ \\
\hline
\end{tabular}


statistics for the 'Sensitive Aquatic Ecosystem GIS layer', showing the number of polygons represented by Quaternary Catchments, and the percentage of Quaternary Catchments containing each of the Sensitivity Priority Groupings. The 'Sensitive Aquatic Ecosystems' layers was based on the same criteria used to indicate quaternary catchments sensitivity from a fish conservation perspective, with fish as indicator of ecosystem vulnerability, and on the same criteria used to developing 'Groundwater Development Potential’ (Fortuin, 2004; Impson et al., 1999).

Only $3.8 \%$ of all the quaternary catchments contain 'Critically Sensitive' aquatic ecosystems associated with the TMG aquifer, with 10.6\% having a 'Very High Sensitivity', $41.2 \%$ having a 'High Sensitivity', $40 \%$ having a 'Medium Sensitivity' and $4.4 \%$ having a 'Low Sensitivity'. The 'Sensitivity' of an aquatic ecosystem within each catchment relate to both the importance from a conservation perspective, and the vulnerability of these catchments to groundwater use from the TMG aquifer.

The $\mathbf{2}^{\text {nd }}$ step of the GIS modelling as given in Fig. 4, culminated in the layer shown in Fig. 7. These geospatial intersections
TABLE 3

Statistics on the percentage of the quaternary catchments containing each 'Sensitivity Priority Group'

\begin{tabular}{|c|c|c|}
\hline $\begin{array}{c}\text { Sensitivity } \\
\text { priority grouping }\end{array}$ & $\begin{array}{c}\text { Number of } \\
\text { polygons }\end{array}$ & $\begin{array}{c}\text { Percentage (\%) in } \\
\text { each group }\end{array}$ \\
\hline Critical & 138 & 3.8 \\
\hline Very high & 382 & 10.6 \\
\hline High & 1484 & 41.2 \\
\hline Medium & 1440 & 40 \\
\hline Low & 159 & 4.4 \\
\hline Total & 3603 & 100 \\
\hline
\end{tabular}

produced the final GIS data layer showing the varying degrees of sensitivity of all the quaternary catchments containing sensitive aquatic ecosystems, including those within the $10 \mathrm{~km}$ buffer area around the TMG aquifer (Xu et al., 2002). This clearly increased the total area of Quaternary catchments that may be sensitive to groundwater use from the TMG aquifer.
Figure 6

Showing the sensitive aquatic ecosystems vulnerable to groundwater use from the TMG

\section{Figure 7}

Sensitive aquatic ecosystems associated with the TMG after intersecting the quaternary catchments with the $10 \mathrm{~km}$ buffer around the TMG aquifer
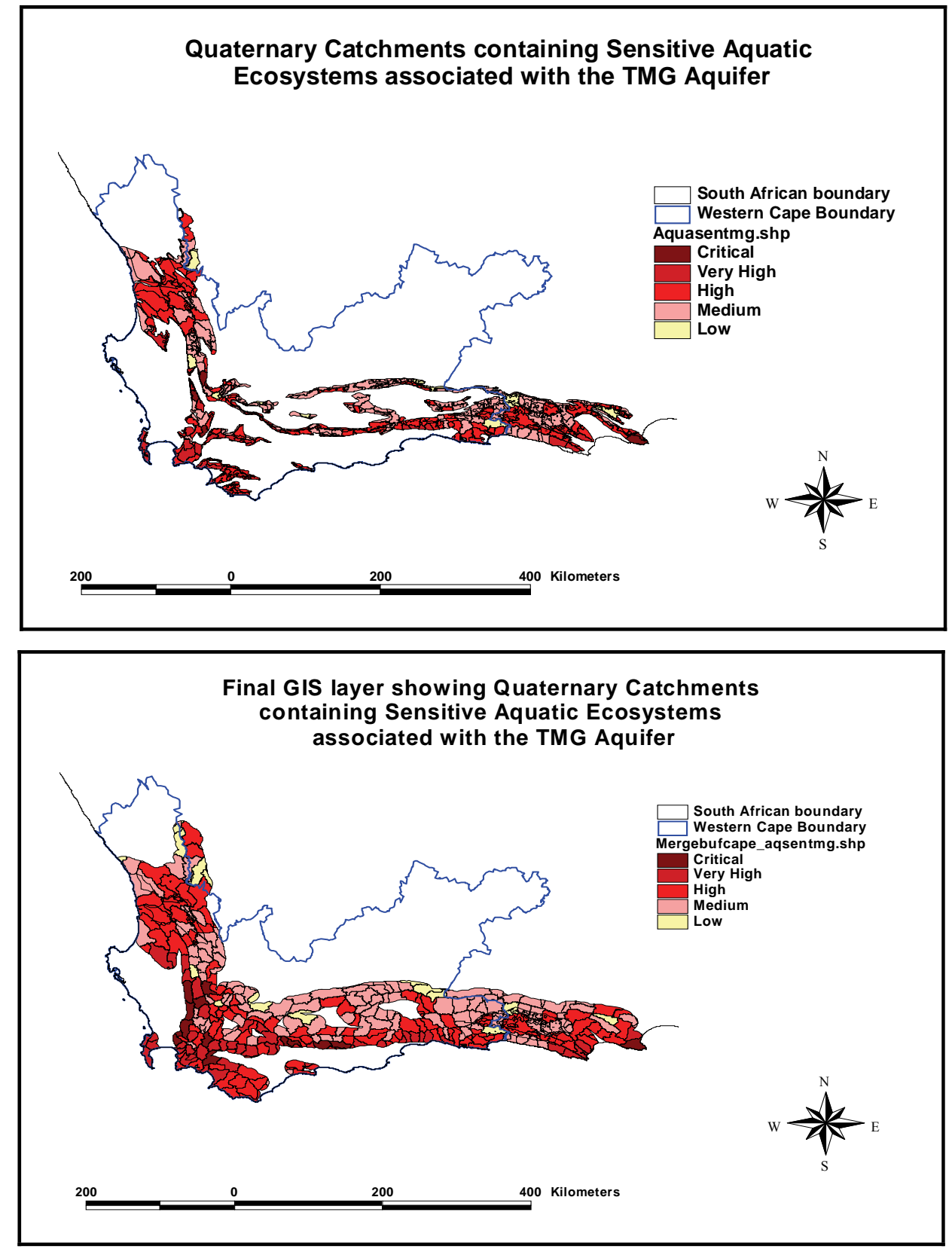


\section{Discussion}

\section{Conceptual model}

The conceptual model clearly shows that the low flows (dry and wet season baseflows) in the mountain and foothill reaches are highly dependent on groundwater discharges from the TMG aquifer. This applies to the 'TMG aquifer daylight-domain'. The important groundwater discharge types in these river reaches for these flow components consists mainly of interflow (normal and rejected TMG aquifer recharge), groundwater discharges from the TMG aquifer (springs, seeps and hyporheic discharges), some delayed translatory flow and limited bank storage may be possible in some geomorphological settings (see Table 1). All these discharges (groundwater and non-groundwater) are highly dependent on the TMG aquifer equilibrium and will be affected when the aquifer equilibrium is changed by groundwater use. Changing the aquifer equilibrium will affect both recharge and discharge of the aquifer. This changed equilibrium will affect both interflow and translatory flow, as both are a function of rejected recharge. If we take into consideration that the groundwater flow is localised in the mountain and foothill reaches, the use from this local aquifer is bound to have an effect on these groundwater discharges.

However, under certain hydrogeological (stratigraphical) conditions the flow may even be regionally affected, if the use of groundwater is high enough. This may result from one of two effects due to the altered aquifer equilibrium, namely:

(a) A drop in the piezometric surface, and

(b) A subsequent drop in the pressure gradient of the aquifer that will affect the hydrological conductivity (capacity of the aquifer to allow through-flow of water), and ultimately affect the discharges from the aquifer.

The asymmetric drawdown cone that can develop along preferential flow paths may extend kilometres away from the well field, having the same effect as in (a). This implies a reduction in the aquifer discharge that may take some time to develop, but it will have an effect. Under these conditions the 'TMG aquifer surface water interface-domain' will also be affected as a result of a reduction in aquifer yield that will affect the TMG aquifer discharges to wetlands, estuaries and marine environments in the lowland settings far away from the recharge areas. Here subsurface hot or cold spring discharges associated with fractures in the confining shale layer, or absence thereof, recharge upper primary aquifers (Fig. 1). Reducing these lowland discharges will significantly affect these wetlands which are groundwater dependent. Discharges to lowland wetlands connected to the TMG would all be ecologically significant.

The lighter coloured blocks of the dry- and wet-season low flows in the headwater river reaches stem from the fact that these streambeds are almost always disconnected from any groundwater table, and it is unlikely to have real groundwater discharges. Groundwater discharges from perched springs may be possible, in which case it is un-related to TMG discharges. In headwater reaches the important baseflow component is completely dominated by normal interflow (non-groundwater). Perennial flows in these reaches may result from recharge events that are close enough to one another to maintain the interflow discharges.

The conceptual model further indicate that flows will become less vulnerable to groundwater use under the higher flow regime components namely, intra-annual floods and large floods. This results from non-groundwater (water not part of the water table) discharges becoming more intense and screening the low flow discharges that are highly vulnerable to groundwater use. Most of the groundwater discharges that contribute to this component of the flow regime in all the river reaches are by this time recharged. However, if the groundwater use has significantly dropped the piezometric surface, it may take longer for the floods (temporal component of the flow regime) to develop and it might affect the flood peak. This may affect the ecological functioning of the aquatic ecosystem in the long run, hence the orange status. In the headwater and mountain reaches interflow still dominates even under the higher flows. The reason for the orange status of the large flood component of the flow regime in the foothill river reach stems from the fact that this river reach is the primary groundwater discharge area in the 'TMG aquifer daylight-domain' (Fig. 1) and the ultimate link between the groundwater and surface water in the TMG.

With regard to the lowland river reaches the most vulnerable part of the flow regime to groundwater use is the dry and wet season baseflow, although this will be indirectly related to the TMG aquifer. Baseflow is the most critical flow for any aquatic ecosystem.

The groundwater discharges from the TMG at the discharge end of the aquifer, as indicated in the model, would all be coloured red because of its ecological significance that is self-evident. These discharges will in all cases support groundwater dependent aquatic ecosystems.

\section{GIS model}

After several geospatial intersections to fine tune the outcome, the sequence of layers, and the successive intersections, gave an effective 'Sensitive Aquatic Ecosystem' layer that successfully linked the TMG aquifer to aquatic ecosystems vulnerable to groundwater use. It was also perfectly synchronised with the sensitive aquatic ecosystem layer of CAPE, and the quaternary catchment layer developed by DWAF. The 'Sensitive Aquatic Ecosystem' layer included all aquatic ecosystems associated with the TMG aquifer in both the "TMG aquifer daylightdomain" and "TMG aquifer surface water interface-domain".

The resultant 'Sensitive Aquatic Ecosystem' layer (Fig. 6) clearly showed the location of all the sensitive aquatic ecosystems within the extent of the TMG aquifer, which had both a high groundwater development potential, and a high conservation value and sensitivity to groundwater use. However, it did not highlight a buffer area around the TMG aquifer within which groundwater use from deep circulation could impact the higher elevation TMG discharges, like springs, seeps and stream discharges in the "TMG aquifer daylight-domain", and or impact on groundwater discharges at the discharge end of the aquifer in the "TMG aquifer surface water interface-domain". Target areas for groundwater use could be located in the deep circulating 'Intermontain domain' (lowland between mountain ranges - Little Karoo) where the confined TMG aquifer is located at great depths producing artesian flow if accessed. Similarly, water used from the TMG aquifer will affect the discharge end of the aquifer, which could be located far from the TMG outcrop areas, in lowland wetlands or marine environments. Hence the need for the inclusion of a buffer area around the TMG to include these scenario's outside the spatial extent of the TMG aquifer. The $\mathbf{2}^{\text {nd }}$ step successfully concluded this requirement by producing the $10 \mathrm{~km}$ buffer area (Xu et al., 2002). This buffer area was also synchronised with the spatially defined quaternary catchments and the "sensitive aquatic ecosystem” layer. 
Any aquifer is in equilibrium, and when groundwater is used it would affect the recharge and the discharge of the aquifer. In all cases the impacts on the TMG aquifer's recharge (mountainous areas) and discharge zones (Intermontain and coastal areas) would result from a change in the aquifer equilibrium.

\section{Conclusions}

\section{Conceptual model}

This conceptual model has clearly demonstrated which groundwater discharge 'types' are contributing to the different components of the flow regime in the different river reaches. It has also successfully shown the relative importance of real groundwater from the TMG aquifer for each flow component in each river reach. With the particular focus of this study on the groundwater interface of the TMG aquifer with surface water, it is clearly the 'real groundwater' discharges that will be mostly affected by groundwater use from the TMG aquifer. Reduced groundwater discharges resulting from groundwater use will be most notable in the mountain and foothill reaches of streams and rivers in the 'TMG aquifer daylight-domain'. It will be the low flows in these reaches that will be most affected. Similarly groundwater discharges at the discharge end of the aquifer will be affected in the 'TMG aquifer groundwater surface water interface-domain', due to the fact that the TMG aquifer is confined to semi-confined and has deep circulation on mainly a regional scale.

Local discharges in the 'TMG aquifer daylight-domain' would be restricted to springs emanating from the TMG where faults affect the confining shale layers, and or at geological contact zones, but hyporheic discharges may be possible in certain settings. Similarly regional discharges from the TMG may be expected in the 'TMG aquifer groundwater surface water interface-domain' where spring discharges may be hot or cold depending on how deep the flow system circulates. These discharges will affect wetlands, estuaries and marine environments.

The reduced groundwater discharges in both domains will result from the potential drop in the piezometric surface, which will ultimately have an effect on the overflow and outflow areas in the mountains, and at the discharge end of local and regional aquifers with varying time scale coupled to that. A lower piezometric head will also cause induced recharge which will affect interflow and translatory flow components.

Groundwater discharges to both domains have been scientifically validated through two separate case studies, one in each of the respective domains, but will be reported on in separate papers. A comparative study on soil nutrient cycling in response to groundwater discharges was used in a case study in the Kammanassie in the 'TMG aquifer daylight-domain', while groundwater quality (hydrochemistry) assessments in lowland wetlands in the Southern Cape confirmed groundwater discharges from the TMG in the "TMG aquifer surface water interface-domain'.

Table 2 clearly shows that the mountain and foothill areas are the most vulnerable to experience reduced baseflow once groundwater is used from the TMG. This is of particular significance because of its essential role in maintaining the ecologically important low- flow conditions (Gilvear et al., 2002; King et al., 2000).

This integrated understanding of the geomorphological, hydrogeological and ecological aspects as highlighted in this paper, shows the importance of integrated water resource planning considering the full hydrological cycle.

\section{GIS model}

Through the current advances in GIS, and existing GIS layers, it was possible to develop a layer highlighting all quaternary catchments vulnerable to groundwater use. It also succeeded in showing the varying degrees of sensitivity of each catchment. Through careful selection of applicable spatially defined layers, and geospatial intersections, a well- defined GIS layer was produced that included a $10 \mathrm{~km}$ buffer area around the TMG.

\section{Acknowledgments}

Special thanks are due to VLIR IUC 'Flemish Interuniversity Counsel', VLIR NSS, Fund Scientific Research Flanders, and the University of the Western Cape for funding this research.

\section{References}

COMMANDER DP (2000) Groundwater Dependent Ecosystems in the Northern Perth Basin (Jurien and Arrowsmith Groundwater Areas). Water and Rivers Commission, Australia.

COWLING RM, PRESSEY RL, LOMBARD AT, HEIJNIS CE, RICHARDSON DM and COLE N (1999) Framework for a Conservation Plan for the Cape Floristic Region, South Africa. Institute for Plant Conservation, University of Cape Town. IPC Report 9902, prepared for WWF-SA.

DAVIES BR, O'KEEFFE JH and SNADDON CD (1993) A Synthesis of the Ecological Functioning, Conservation and Management of Southern African River Ecosystems. WRC Report No. TT 62/93. Water Research Commission, Pretoria, South Africa.

FORTUIN M (2004) A Geographic Information Systems Approach to the Identification of Table Mountain Group Aquifer 'Type Areas' of Ecological Importance. M.Sc. Thesis, UWC, Cape Town.

GILVEAR DJ, HEAL KV and STEPHEN A (2002) Hydrology and ecological quality of Scottish river ecosystems. Sci. Total Environ. 294 131-159.

HEYWOOD I, CORNELIUS S and CARVER S (2002) An Introduction to Geographical Information Systems ( $2^{\text {nd }}$ edn.). Pearson Education Limited, Essex, CM2O 2JE, England.

IMPSON ND, BILLS IR, CAMBRAY JA and LE ROUX A (1999) The Primary Freshwater Fishes of the Cape Floristic Region: Conservation Needs for a Unique and Highly Threatened Fauna. Cape Nature Conservation Report to the University of Cape Town for the CAPE Conservation Planning Analysis. pp 26.

KING JM, BROWN CA and SABET H (2003) A scenario-based holistic approach to environmental flow assessments for regulated rivers. Rivers Res. Appl. 19 (5-6) 619-640.

KING JM, THARME RE and DE VILLIERS MS (2000) Environmental Flow Assessments For Rivers: Manual for the Building Block Methodology. WRC Report No. TT 131/00. Water Research Commission, Pretoria, South Africa.

KOTZE JC (2002) Hydrogeology of the Table Mountain Sandstone Aquifer - Klein Karoo. Ph.D. Thesis, University of the Free State, Bloemfontein, South Africa..

LOW AB and ROBELO AG (1996) Vegetation of South Africa, Lesotho and Swaziland. Department of Environmental Affairs and Tourism, Pretoria.

MIDGLEY JJ and SCOTT DF (1994) The use of stable isotopes of water (D and ${ }^{18} \mathrm{O}$ ) in hydrological studies in the Jonkershoek Valley. Water SA 20 (2) 151-154.

MOON BP and DARDIS GF (1988) The Geomorphology of Southern Africa. Southern Book Publishers (Pty) Ltd., Johannesburg, South Africa.

SEMENIUK CA and SEMENIUK VA (1994) A geomorphic approach to a global classification for inland wetlands. Vegetation 118.

WARD RC and ROBINSON M (1990) Principles of Hydrology ( ${ }^{\text {rd }}$ edn.). McGraw-Hill Publishing Company. England. 
WINTER TC, HARVEY JW, FRANKE OL and ALLEY WM (1999) Ground Water and Surface Water: A Single Resource. US Geological Survey, Denver, Colorado.

XU Y and BEEKMAN HE (EDS) (2003) Groundwater Recharge Estimates in Southern Africa. UNESCO IHP Series No.64, UNESCO Paris. ISBN 92-9220-000-3.
XU Y, TITUS R, HOLNESS SD, ZHANG J and VAN TONDER GJ (2002) A hydrogeomorphological approach to quantification of groundwater discharge to streams in South Africa. Water SA 28 (4) 375-380. 